\title{
СОЦІАЛЬНО-ПСИХОЛОГІЧНІ ОСОБЛИВОСТІ САМОРЕГУЛЯЦІї ПІДЛІТКІВ
}

У статті проаналізовано соціально-психологічні особливості саморегуляції підлітків. Визначено, щзо саморегуляція підлітків формується під впливом сочіально-психологічних чинників, які здатні перетворитися в регулювальні способи поведінки, внаслідок чого з'являються різні психологічні новоутворення, підвищується або знижується рівень особистісної системи, змінюється режим ї̈ функиіонування. Зроблена спроба пояснити регулячіюю поведінки підлітків через побудову структурно-функціональної моделі, яка включає: самооцінку, рівень домагань, життєві иілі і ичінності, локус контролю, мотивацію досягнення. Таким чином, процес саморегулячії відображається як иілісна, інформаџійно відкрита система, котра постійно зазнає як зовнішнього, так і внутрішнього впливу.

Ключові слова: підлітковий вік, саморегуляція, самооцінка, локус контролю, “Я-концепція”.

Постановка проблеми. Підлітковий вік справедливо вважається одним із найскладніших періодів життя людини. Підлітки часто пробують себе в різних сферах і не можуть завершити розпочаті справи, емоційно реагують на звичні ситуації і взагалі мають проблеми із саморегуляцією. Як наукова проблема саморегуляція підлітків вирізняється складністю, багатомірністю та неоднозначністю. Все це через те, що саморегуляція $є$ провідним і важливим психічним процесом будь-якого виду життєдіяльності особистості, а особливо - у підлітковому віці. Адже на будь-якому віковому етапі процес входження індивіда в суспільство вимагає засвоєння ним соціальних норм, цінностей та досвіду, необхідних для успішної життєдіяльності. Саме тому у період дорослішання особливо складною виявляється саморегуляція поведінки підлітків. Адже вони вирізняються неадекватними психогенними реакціями, нескоординованими формами поведінки, дезадаптивними вчинками, що визначає необхідність вивчення феномена саморегуляції в перехідному віці. Слід зауважити, що в цей період спостерігається становлення естетичних смаків, ціннісних орієнтацій та моральних переконань, на основі яких починають регулювати свою поведінку.

Аналіз останніх досліджень і публікацій. Проблема психологічних чинників саморегуляції поведінки людини досліджувалася і постійно актуалізується вченими різних напрямів психологічної науки. У працях І.Д. Беха, М.Й. Боришевського, С.Д. Максименка, М.В. Савчина, О.Я. Чебикіна знаходять висвітлення питання активності людини як суб'єкта власної діяльності та поведінки. Предметом вивчення зарубіжних вчених (Д. Аткінсон, Д. Роттер, Х. Хекхаузен, Г. Шерінгтон) були мотиваційні установки: життєві цілі, прагнення до успіху, локус контролю, когнітивний дисонанс. Щодо вивчення особливостей саморегуляції поведінки зростаючої особистості, зокрема підлітків, можна виділити цілий ряд робіт сучасних українських вчених (Д.М. Чижми, В.І. Ілійчука, Т.В. Кириченко та ін.). Таким чином, саморегуляція $\epsilon$ функціональною характеристикою особистості, процесом взаємозв'язку та взаємоузгодження різних завдань зі станом суб'єкта.

Загальноприйнятим $є$ визначення саморегуляції як системи психічного самовпливу 3 метою свідомого управління особистістю своїми психічними станами у відповідності 3 вимогами ситуації та доцільністю. Саморегуляція може здійснюватися на неусвідомленому рівні за допомогою підтримки внутрішнього гомеостазу і пристосувальної поведінки (наприклад, ситуація небезпеки викликає стан напруги, тривоги, стресу, готовності діяти) та бути свідомим, довільним процесом на основі засвоєння спеціальних методів мобілізації внутрішнього потенціалу людини, котрий у звичайному житті $\epsilon$ неактуалізованим. Соціально-психологічні чинники формування саморегуляції закріплюються у психологічній організації особистості як функціональні способи ії перетворень, у результаті яких з'являються різні психологічні новоутворення, підвищується або знижується рівень особистісної системи, змінюється режим ії функціонування. Щоб пояснити регуляцію поведінки було введено ряд понять: рівень домагань, життєві цілі, локус контролю, 
мотивація досягнення [5]. До структурно-функціональних складових системи саморегуляції особистості відносяться цінності, цілі, ідеали, образ “Я”, рівень домагань та самооцінка $[3 ; 4 ; 6]$.

B.I. Ілійчук розглядає саморегуляцію у взаємозв'язку з різними компонентами самосвідомості (такими як Я-концепція, самоставлення, спрямованість, мотивація, часова перспектива, ціннісні орієнтації, життєві цілі, ідеали) та їх регуляторними властивостями [4].

Цікавою є думка дослідниці Т.В. Кириченко. Вона виділяє такі механізми процесу саморегуляції в підлітковому віці: рівень домагань, ціннісні орієнтації, локус контролю, мотивація схвалення, потреби у досягнення успіху. При цьому, автор вважає, що всі виділені механізми перебувають у постійній взаємодії [5].

Мета статті - визначити соціально-психологічні особливості саморегуляції підлітків.

Виклад основного матеріалу і результатів дослідження. Психологічні механізми саморегуляції поведінки особистості підлітка є структурним утворенням самосвідомості, що інтегрує у собі здатність визначати ціннісні орієнтації, здібність досягати мети адекватно внутрішнім потенціалам, можливість самоконтролю, прагнення до успіху (самореалізації), потребу соціального самоствердження та визнання. Специфіка психологічних механізмів саморегуляції поведінки зростаючої особистості полягає в тому, що кожний психологічний механізм має автономний рівень розвитку і в той же час дане особистісне утворення лише в цілісності виступає регулятором поведінки підлітка.

На основі проведеного аналізу соціально-психологічних чинників саморегуляції поведінки підлітків, можна побудувати структурно-функціональну модель взаємозв'язку цих чинників між собою. Найважливішим регулятором, своєрідним фундаментом, 3 якого можна розпочати модель, ми вважаємо цінності. Адже саме цінності виступають тією основою, з якої починають формуватися ідеали, цілі та соціальні очікування.

Наступним важливим елементом ми назвемо самооцінку, яка знаходиться у взаємозв’язку з образом “я”. Самооцінка формується під впливом соціальних очікувань. Проявляється вплив ставлення оточуючих людей до конкретного індивіда. Якщо йде схвалення певної поведінки підлітка, то його самооцінка піднімається (зміцнюється у своїх позиціях), якщо, навпаки, осуд, тоді самооцінка знижується.

Також значний вплив на рівень самооцінки виконує рівень домагань. Коли вимоги підлітка до себе високі і він виконує поставлені перед собою завдання, відповідно самооцінка підсилюється. Те ж можна сказати про поставлені перед підлітком невиконані задачі, які підривають його самооцінку. Рівень домагань у свою чергу має прямий вплив на цілі, які підліток буде формувати перед собою в залежності від поставлених до себе вимог. Відповідне коригування рівня домагань впливає як на самооцінку підлітка, так і на його образ “Я”, а також на потреби у досягненні успіху.

Багатьом підліткам властива потреба у досягненні успіху (робити щось краще за всіх), бути лідером серед однолітків. Саме від цього чинника підлітки можуть формувати перед собою цілі. На нашу думку, такі потреби мають вплив на самооцінку і взаємовплив 3 образом “Я”. У свою чергу соціальні очікування однолітків, батьків, вчителів чи інших важливих для підлітка осіб корегують його потреби у досягненні успіху, впливають на образ “Я”, самооцінку, локус контролю та на його цілі.

Таким чином можна описати кожен з соціально-психологічних чинників саморегуляції підлітків. Нами описані найбільш впливові, на нашу думку, взаємозв'язки і побудована структурно-функціональна модель чинників саморегуляції підлітків.

Ми вважаємо, що всі описані чинники взаємопов'язані між собою і їх коливання загалом і впливає на саморегуляцію поведінки людей, в тому числі підлітків. Завдяки регуляторним процесам людина спроможна ставити перед собою свідомі цілі, будувати концепцію їх досягнення, розвивати власні психічні особливості. 
Коли розглядати внутрішньогрупову взаємодію підлітків та прояви саморегуляції у ній, можливо з'ясувати закономірності і механізми, що підпорядковують поведінку конкретного індивіда у реальній соціальній групі. Адже в залежності де і з ким перебуває в конкретний момент підліток, на його поведінку і здійснення саморегуляції будуть впливати конкретні чинники.

Так, наприклад, коли підліток знаходиться в школі у своєму класі на уроці, то його саморегуляція буде здійснюватися, на нашу думку, через соціальні очікування вчителів, якщо підліток буде на перерві серед однолітків, то його поведінка буде відповідати, в першу чергу, соціальним очікуванням його шкільної групи, їх цінностям, цілям та ідеалам. у залежності від самоідентифікації свого образу “Я” на відповідність педагогічним, груповим соціальним очікуванням (ідеалам чи цілям) буде балансувати самооцінка підлітка і коригуватися власна поведінка відповідно до неї (самооцінки). А також будуть зазнавати змін власні цілі, цінності та ідеали. Саме тому саморегуляція постає специфічною формою взаємодії людини з навколишнім світом, виявляючись у самодетермінації, контролі своєї поведінки, виробленні вольових якостей, свідомій постановці завдань, мобілізації психічних і фізичних потенціалів у досягненні поставлених цілей, виробленні стилю взаємодії з іншими.

Таким чином, процес саморегуляції відображається як цілісна, замкнута, інформаційно відкрита система, котра постійно зазнає як зовнішнього, так і внутрішнього впливу. Структурно повноцінний регуляторний процес неминучий в успішному досягненні суб'єктом поставленої мети.

Вважаємо, що завдяки запропонованій моделі функціональної структури психічної саморегуляції батьки, педагоги можуть здійснювати найбільш оптимальну й ефективну побудову процесу саморегуляції підлітків, використовувати ії найрізноманітніші форми.

Подальше дослідження зазначеної проблеми може бути спрямоване на емпіричну перевірку структурних компонентів теоретичної моделі.

Висновки. Таким чином, нами обгрунтовані теоретичні аспекти поняття саморегуляції, які були розглянуті у психологічній науці багатьма вченими під різними кутами зору, описані та проаналізовані провідні соціально-психологічні чинники саморегуляції поведінки підлітків (цінності, цілі, ідеали, рівень домагань, локус контролю, образ Я та ін.) та визначені їх особливості формування у підлітковому віці; структуровано отримані дані та на їх основі побудовано структурно-функціональну модель чинників саморегуляції поведінки підлітків, запропоновано бачення підходу щодо впливу на саморегуляцію поведінки, що полягає у виявленні специфіки, динаміки, взаємозв'язків між провідними механізмами, застосуванні психолого-педагогічних методів, що впливають на процес становлення саморегуляції поведінки підлітків. Встановлено, що саморегуляція поведінки розглядається як єдність соціальних та психологічних (вольових, рефлексивних, мотиваційних) проявів свідомості й самосвідомості індивіда; сукупність установок, вчинків, дій, завдяки яким особистість здійснює власну поведінку, обираючи адекватні та морально виважені засоби іiі втілення в навколишньому світі. Проведений аналіз та запропонована структурно-функціональна модель чинників саморегуляції поведінки потребує подальшої емпіричної перевірки.

1. Бех І. Д. Вибрані наукові праці. Виховання особистості. Чернівці : Букрек, 2015. 640 с.

2. Боришевський М. Й. Дорога до себе. Від основ суб'єктності до вершин духовності. Київ : Академвидав, 2010. $158 \mathrm{c}$.

3. Галян I. М. Психологічний аналіз сутності саморегуляції як особистісної здатності. Збірник наукових праџь: філософія, соиіологія, психологія. Івано-Франківськ : Вид-во ДВНЗ “Прикарпатський національний університет імені Василя Стефаника”, 2015. Вип. 20. Ч. 1. С. 154-161.

4. Ілійчук В. І. Саморегуляція підлітків у подоланні конфліктної поведінки : дис. ... канд. психол. наук : 19.00.07 / Прикарпатський ун-т ім. В. Стефаника. Івано-Франківськ, 1996. 192 с.

5. Кириченко Т. В. Механізми саморегуляції поведінки як психологічні умови формування особистості. Гуманітарний вісник ДВНЗ “Переяслав-Хмельницький державний педагогічний 
університет імені Григорія Сковороди” : збірник наукових праць. Переяслав-Хмельницький, 2011. Вип. 21. С. 385-389.

6. Rotter J. B. Some problems and misconceptions related to the construct of internal versus external control of reinforcement. Journal of Consulting and Clinical Psychology. 1975. Vol. 43. P. 56-67. 